\title{
Geochemical Evaluation of Arimogija-Okeluse Limestones, Eastern Dahomey Basin, Southwestern Nigeria
}

\author{
Edema Abayomi ${ }^{1,}$, Owonipa Omoniyi Dare ${ }^{2,}$ \\ ${ }^{1}$ Department of Geological Sciences, Achievers University, Owo, Nigeria \\ ${ }^{2}$ Earth Sciences Department, Kogi State University, Anyigba. Nigeria \\ *edemayomi07@yahoo.com
}

Keywords: Limestone, Strontium, Arimogija-Okeluse, Cement.

\begin{abstract}
Arimogija- Okeluse Axis of the Dahomey Basin and subjected to X-Ray Fluorescence analysis. Major and Trace elements were used to classify and predict the depositional environment of Arimogija-Okeluse limestone. The results for the major oxide composition revealed that $\mathrm{CaO}$ content ranges from 47.6-52.31\% with a mean value of $50.06 \% . \mathrm{SiO}_{2}$ concentration varies from $1.94-5.24 \%$ with an average of $3.36 \%$. $\mathrm{Fe}_{2} \mathrm{O}_{3}$. $\mathrm{MgO}$, and $\mathrm{Al}_{2} \mathrm{O}_{3}$ contents have mean values of $1.702 \%, 1.52 \%$, and $1.09 \%$ respectively. Other oxides; $\mathrm{Na}_{2} \mathrm{O}, \mathrm{P}_{2} \mathrm{O}_{5}, \mathrm{~K}_{2} \mathrm{O}$ and $\mathrm{TiO}_{2}$ are low in concentration. The Loss on Ignition also varies from 38.9-41.8 with a mean value of $40.43 \%$ suggesting a high carbonate content for the limestone. Standard $\mathrm{Ca} / \mathrm{Mg}$ and $\mathrm{Mg} / \mathrm{Ca}$ ratios varies from 25.87-37.63 and 0.03-0.04 with a mean of 33.31 and 0.031 respectively. The high strontium content reveals a saline environmental condition of formation for the limestone.

The results obtained showed that the Arimogija-Okeluse limestone is a Magnesian limestone deposited in a shallow marine environment and suitable for cement production.
\end{abstract}

\section{Introduction}

Limestone is the most abundant commodity with a global industrial use. A wide range of products has been made from limestone and its by-products. Such products include fertilizers, refractory fillers, ceramics and paints. Limestone has been mined for cement production. The suitability of limestone for cement production is a function of its chemical characteristics, hence the reason for this work.

A knowledge of the purity status of the limestone in the Arimogija - Okeluse area will guide prospective investors and stakeholders in decision making and thus subsequent establishment of a cement factory in the zone. A good number of limestone occurrence in Nigeria has been reported; $[1,2,3,4,5$,

Published works on Arimogija - Okeluse limestone are rare. Very few studies have been carried out on the Arimogija - Okeluse sub-basin. Ehinola et al [5] worked on the depositional environment, geophysical mapping and reserve estimation of the limestone deposit. Ola- Buraimo et al [7] did a Palynological Investigation of a Type Section of Early Maastrichtian Arimogija - Okeluse Shale Sequence. Unlike other research work done on the Arimogija-Okeluse Axis, little or no work has been done on the quality of the limestone. However, this work is aimed at bridging the information gap via geochemical criterion using major and trace element analysis to classify and predict the depositional environment of Arimogija-Okeluse limestone.

\section{Geologic Setting}

The Dahomey Basin is a sedimentary basin that extends from south-eastern Ghana in the west to the western flank of Niger Delta in Nigeria. It is bounded in the west by the Ghana ridge, which is an extension of the Romanche Fracture Zone; and on the east, by the Benin Hinge line, a basement escarpment which separates the Okitipupa Structure from the Niger Delta Basin and also marks the continental extension of the Chain Fracture Zone [8]. The Nigeria portion of the basin extends from 
the boundary between Nigeria and Republic of Benin to the Benin Hinge Line. The stratigraphy of the sediments in the Nigerian sector of the Dahomey Basin is controversial. This is primarily because different stratigraphic names have been proposed for the same formation in different localities in the basin [9]. This situation can be partly blamed on the lack of good borehole coverage and adequate outcrops for detailed stratigraphic studies.

The stratigraphy of the entire basin into three chronostratigraphic packages; they are pre - lower Cretaceous folded sediments, Cretaceous sediments and Tertiary sediments [10]. In the Nigerian portion of the basin, the Cretaceous sequence, as compiled from outcrop and borehole records, consists of the Abeokuta Group which is sub- divided into three formational units: Ise, Afowo, and Araromi Formations [11]. Ise Formation unconformably overlies the basement complex and comprises of coarse conglomeratic sediments. Afowo Formation is composed of transitional to marine sands and sandstone with variable but thick interbedded shales and siltstone. Araromi is the uppermost formation and is made up of shales and siltstone with interbeds of limestone and sands The Tertiary sediments consist of Ewekoro, Akinbo, Oshosun, Ilaro and Benin (coastal plain sand) Formations. Ewekoro Formation is made up of fossiliferous, well-bedded limestone while Akinbo and Oshosun Formations are made up of flaggy grey and black shales. Glauconitic rock bands and phosphatic beds define the boundary between the Ewekoro and Akinbo Formations. Ilaro and Benin Formations are predominantly coarse sandy estuarine, deltaic and continental beds [12]. The shale limestone sequence at Arimogija - Okeluse belong to the Cretaceous Abeokuta Formation which was deposited during the first marine transgressive cycle in the Dahomey basin.

The study area lies within longitude $5^{\circ} 33^{\prime} \mathrm{E}-5^{\circ} 43^{\prime} \mathrm{E}$ and latitude $6^{\circ} 46^{\prime} \mathrm{N}-6^{\circ} 51^{\prime} \mathrm{N}$ at the easternmost part of the Dahomey Basin with elevation range between 50 and 80 meters. (Fig. 1). The mapped area is part of the Cretaceous Abeokuta Group

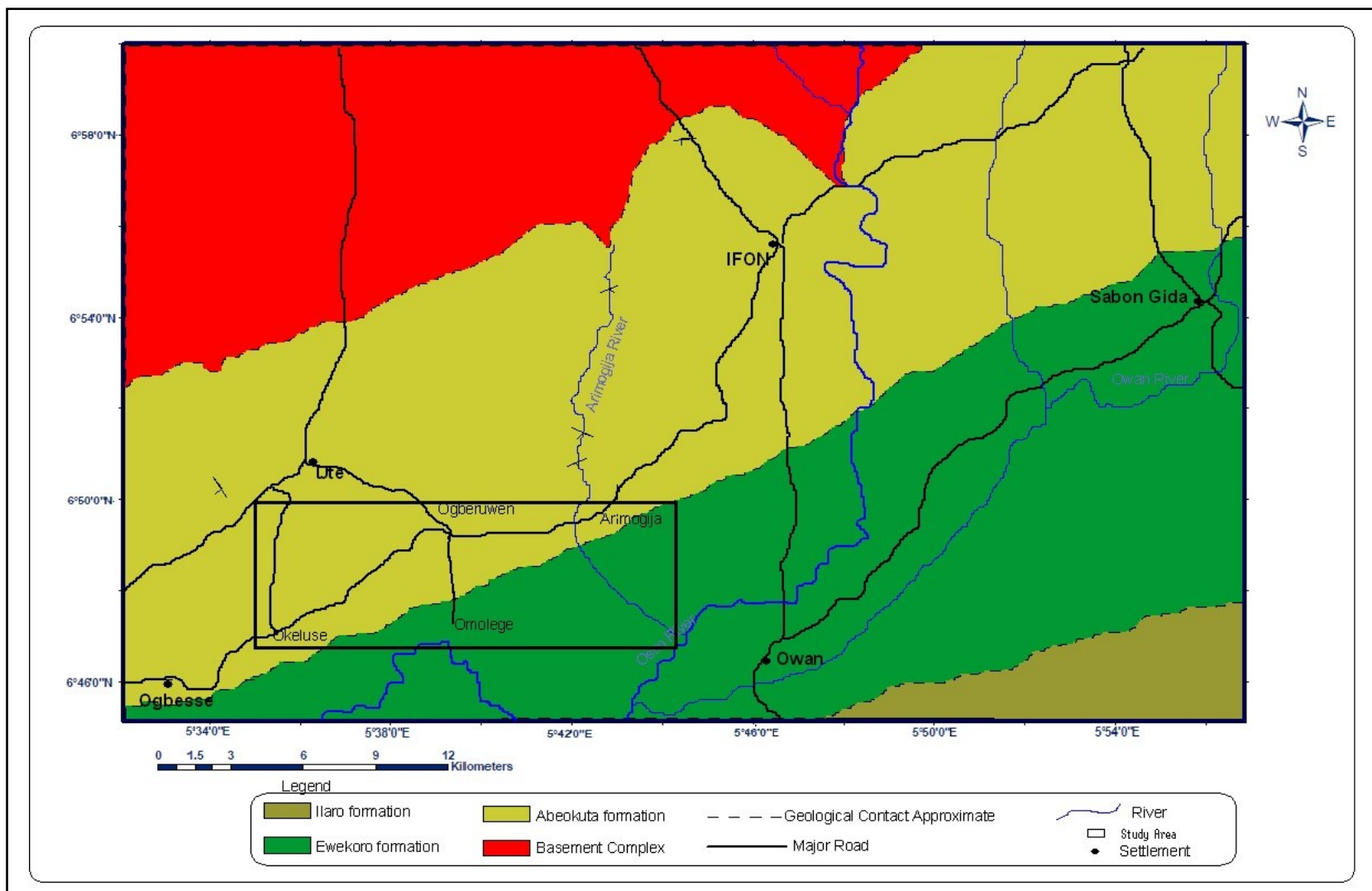

Fig. 1: Geological Map of Arimogija Okeluse Axis (Adapted from Ehinola et al [5]) 


\section{Materials and Methods}

10 representative samples of limestone were collected from the Arimogija-Okeluse sub-basin. The collected samples were appropriately labelled and georeferenced. These samples were further subjected to geochemical analysis via the X-Ray Fluorescence method after being pulverised and sieved with $65 \mu$ mesh. Concentrations of the major elements were determined on fused lithiummetaborate discs by X-ray fluorescence spectrometry (Philips PW1400 Spectrometer) at Activation laboratory using an $\mathrm{Rh}$ tube operated at $40 \mathrm{kV}$ and $70 \mathrm{~mA}$. Loss on ignition (LOI) was determined by heating powdered samples for $50 \mathrm{~min}$ at $1000{ }^{\circ} \mathrm{C}$. The concentrations of $\mathrm{Ba}, \mathrm{Sr}, \mathrm{Zr}$, were also determined on pressed pellets by X-Ray Fluorescence spectrometry at Activation Laboratory (operating conditions: $\mathrm{Rh}$ radiation, $70 \mathrm{kV}, 40 \mathrm{~mA}$ ).

\section{Results and discussion}

\section{Sediment Chemistry}

\subsection{Major Oxides}

The result of major elemental oxides (Table 1) for the analysed samples show that the concentration of $\mathrm{CaO}$ ranges from $47.6-52.31 \%$ with an average of $50.06 \%$. The $\mathrm{SiO}_{2}$ content varies from $1.94-$ $5.24 \%$ with a mean of $3.36 \%$ and $\mathrm{Fe}_{2} \mathrm{O}_{3}$ ranges between $1.2-2.54 \%$ with a mean of $1.70 \%$ while $\mathrm{MgO}$ and $\mathrm{Al}_{2} \mathrm{O}_{3}$ contents vary from $1.39-1.84 \%$ and $0.61-1.82 \%$ with average values of 1.52 and $1.09 \%$ respectively. Other oxides; $\mathrm{Na}_{2} \mathrm{O}, \mathrm{P}_{2} \mathrm{O}_{5}, \mathrm{k}_{2} \mathrm{O}$ and $\mathrm{TiO}_{2}$ are low in concentration with average values of $1.52,0.90,0.1,0.05$ and $0.08 \%$ respectively (Table 1 ). The Loss on Ignition also varies from $38.9-41.8$ with a mean of $40.43 \%$

Table 1: Major Oxides (\%) Concentrations for Arimogija-Okeluse Limestone

\begin{tabular}{llllllllllll}
\hline SAMPLE ID & $\mathbf{S i O}_{2}$ & $\mathbf{A l}_{2} \mathbf{O}_{3}$ & $\mathrm{Fe}_{2} \mathbf{O}_{3}$ & $\mathbf{M g O}$ & $\mathbf{C a O}$ & $\mathbf{N a}_{2} \mathbf{O}$ & $\mathbf{K}_{2} \mathbf{O}$ & $\mathbf{T i O}_{2}$ & $\mathbf{P}_{2} \mathbf{O}_{5}$ & $\mathbf{M n O}$ & $\mathbf{L O I}$ \\
\hline ARS1 & 4.52 & 1.79 & 2.03 & 1.76 & 48.60 & 0.02 & 0.07 & 0.13 & 1.31 & 0.1 & 39.5 \\
ARS2 & 5.24 & 1.82 & 2.54 & 1.84 & 47.60 & 0.02 & 0.06 & 0.13 & 1.42 & 0.1 & 38.9 \\
ARS3 & 3.89 & 0.97 & 1.89 & 1.43 & 49.20 & 0.02 & 0.06 & 0.12 & 1.29 & 0.1 & 40.2 \\
ARS4 & 4.58 & 1.57 & 2.41 & 1.60 & 48.67 & 0.02 & 0.06 & 0.13 & 1.33 & 0.1 & 39.5 \\
ARS5 & 4.78 & 1.66 & 2.03 & 1.58 & 47.89 & 0.02 & 0.07 & 0.12 & 1.30 & 0.1 & 39.8 \\
OKL6 & 1.94 & 0.61 & 1.20 & 1.39 & 52.31 & 0.02 & 0.04 & 0.03 & 0.43 & 0.1 & 41.8 \\
OKL7 & 1.96 & 0.61 & 1.22 & 1.40 & 51.98 & 0.02 & 0.04 & 0.03 & 0.47 & 0.1 & 41.2 \\
OKL8 & 2.54 & 0.61 & 1.22 & 1.40 & 50.06 & 0.02 & 0.05 & 0.03 & 0.51 & 0.1 & 40.9 \\
OKL9 & 1.99 & 0.61 & 1.28 & 1.42 & 52.22 & 0.02 & 0.05 & 0.03 & 0.48 & 0.1 & 41.3 \\
OKL10 & 2.16 & 0.61 & 1.20 & 1.40 & 52.04 & 0.02 & 0.04 & 0.03 & 0.47 & 0.1 & 41.2 \\
MEAN & 3.36 & 1.09 & 1.70 & 1.52 & 50.06 & 0.02 & 0.05 & 0.07 & 0.90 & 0.1 & 40.4 \\
\hline
\end{tabular}

ARS: Arimogija Limestones, OKL: Okeluse Limestones

\section{$\mathrm{CaO}$; Calcium Oxide and $\mathrm{SiO}_{2}$; Silica}

From the result of the major oxides, $\mathrm{CaO}$ is prevailing, Table 1 . $\mathrm{CaO}$ shows an inverse relation with silica $\mathrm{SiO}_{2}$. Relatively, high value of $\mathrm{CaO}$ shows a low value of $\mathrm{MgO}$. Comparatively, high level of $\mathrm{CaO}$ and low values of silica and $\mathrm{MgO}$ show a high degree of purity of the limestone. This makes it fit for cement production.

The $\mathrm{CaO}$ at Arimogija- Okeluse compares satisfactorily with that of Olade [2]but it displays a strong low when compared to that of Sagamu (89.2\%,), Ewekoro $(80.3 \%)$ and Ibeshe (75.7\%) [4], Table 2. Ehinola et al [5] reported a highly fossiliferous limestone for the Arimogija Okeluse limestone and thus classify it as a bioclast wackestone. These carbonate grains are derived from the reworking of shelf carbonate allochems during transgression $[13,14]$. 
Mean $\mathrm{SiO}_{2}$ values of $13.9 \%$ and $11.3 \%$ for Igunmale and Sokoto respectively [2]. The Silica concentration of Arimogija-Okeluse limestone (3.36\%) is low relative to other limestones deposits in Nigeria. However, it is almost at par with that of Sagamu, Ewekoro and Ibeshe with mean values of $5.7 \%, 8.7 \%$ and $14.8 \%$ respectively, [4]. This study however established that Arimogija-Okeluse limestone is a low silica limestone, hence it is of high grade

\section{Alumina $\left(\mathrm{Al}_{2} \mathrm{O}_{3}\right)$ and Magnesium Oxides (MgO)}

Relative to the concentration of $\mathrm{CaO}$, Alumina and Magnesium oxide concentrations are low with mean values of $1.09 \%$ and $1.52 \%$ respectively [2]. The low concentration of alumina suggests a low energy environment. The skeletal debris of marine invertebrate has low magnesium with increasing level in the phyla, [15]. Arimogija - Okeluse limestone is rich in brachiopods, gastropods, bivalves, and shell fragments of echinoids and ostracods which are typical of an open shelf environment [5]. The presence of these invertebrates is suspected to be responsible for the low level of magnesium in the samples. Magnesium concentration is also a function of temperature of formation, and often low in shells living in shallow waters [16]. Consequently, shallow marine environment is therefore proposed for Arimogija - Okeluse limestone.

Table 2: Analytical Data of Other Comparable Limestones in Nigeria (\%)

\begin{tabular}{|c|c|c|c|c|c|c|c|c|c|c|c|}
\hline & $\mathrm{SiO}_{2}$ & $\mathbf{A l}_{2} \mathbf{O}_{3}$ & $\mathrm{Fe}_{2} \mathrm{O}_{3}$ & MgO & $\mathrm{CaO}$ & $\mathrm{Na}_{2} \mathrm{O}$ & $\mathbf{K}_{2} \mathbf{O}$ & $\mathrm{TiO}_{2}$ & $\mathbf{P}_{2} \mathbf{O}_{5}$ & MnO & LOI \\
\hline $\begin{array}{l}\text { RelativelyPure } \\
\text { Limestone [17] }\end{array}$ & 1.88 & 0.83 & 0.26 & 2.75 & 50.89 & 0.06 & 0.01 & 0.01 & 0.01 & 0.01 & \\
\hline This study & 3.36 & 1.09 & 1.70 & 1.52 & 50.06 & 0.02 & 0.05 & 0.08 & 0.90 & 0.10 & 40.4 \\
\hline $\begin{array}{l}\text { Tse-Kucha } \\
\text { Limestone [6] }\end{array}$ & 6.40 & 2.20 & 1.40 & 0.70 & 48.20 & 0.09 & 0.48 & 0.11 & 0.11 & 0.13 & 40.12 \\
\hline Nkalagu [18] & 5.90 & 1.30 & 0.77 & 0.99 & 49.74 & - & - & - & - & - & - \\
\hline $\begin{array}{l}\text { Middle Belt } \\
\text { Zone [19] }\end{array}$ & 0.53 & 0.07 & 0.04 & 1.77 & 52.17 & 0.19 & 0.13 & 0.01 & - & 0.07 & 44.97 \\
\hline $\begin{array}{l}\text { Gboko } \\
\text { Limestone [20] }\end{array}$ & 9.78 & 1.48 & 2.20 & 1.99 & 48.88 & 0.05 & 0.01 & - & - & - & 36.57 \\
\hline $\begin{array}{l}\text { Mfamosing } \\
\text { Limestone [21] }\end{array}$ & 0.25 & 0.35 & & 0.15 & 56.12 & 0.01 & 0.03 & - & - & - & - \\
\hline Sagamu [4] & 5.70 & & & & 89.20 & & & & & & \\
\hline
\end{tabular}

\section{Classification of Limestone}

Pettijohn, [17], have classified limestone. However, the classification of limestone in the study area is made after Todd, [22]. The standard ratio; $\mathrm{Ca} / \mathrm{Mg}$ ratio and its reciprocal ratio: $\mathrm{Mg} / \mathrm{Ca}$ was employed by Todd [22] as a parameter for Chemical Classification of limestone. Todd [22] grouped Limestone samples with $\mathrm{Ca} / \mathrm{Mg}$ ratios with a range of $1.41 \%-12.30 \%$ as Dolomitic Limestone, samples with $\mathrm{Ca} / \mathrm{Mg}$ ratio of $12.30 \%-39.00 \%$ as "Magnesian Limestone" and Limestone samples having $39.00 \%$ to $100 \%$ are grouped as "Pure Limestone" Table 3.

Table 3: Chemical Classification of Limestone [22]

\begin{tabular}{lll}
\hline Descriptive term & Standard ratio Ca/Mg & Reciprocal Ratio Mg/Ca \\
\hline Dolomitic Limestone & $12.30-1.41$ & $0.08-0.18$ \\
Magnesian Limestone & $39.00-12.30$ & $0.03-0.08$ \\
Pure Limestone & $100.00-39.00$ & $0.00-0.18$
\end{tabular}

However, the standard $\mathrm{Ca} / \mathrm{Mg}$ ratio varies from 25.87 to 37.63 while the reciprocal ratio $\mathrm{Mg} / \mathrm{Ca}$ ranges from $0.03-0.04$. This result reveals that the limestone deposit in Arimogija - Okeluse is the Magnesian limestone type (Table 4). 
$\mathrm{The} \mathrm{Ca} / \mathrm{Mg}$ ratio also corresponds to stability condition during the formation of carbonate rock [23]. He pointed out that the degree of salinity increases with decrease in $\mathrm{Ca} / \mathrm{Mg}$ ratio. Higher values of $\mathrm{Ca} / \mathrm{Mg}$ ratio of the studied carbonate indicates comparatively less evaporation of sea water and low salinity which prevailed during the formation of limestone in general.

Table 4: Chemical classification of Arimogija - Okeluse Limestone

\begin{tabular}{llllll}
\hline SAMPLE ID & MgO & $\mathbf{C a O}$ & $\mathbf{C a} / \mathbf{M g}$ & $\mathbf{M g} / \mathbf{C a}$ & Remarks \\
\hline ARS1 & 1.76 & 48.60 & 27.61 & 0.0362 & Magnesian Limestone \\
ARS2 & 1.84 & 47.60 & 25.87 & 0.0387 & Magnesian Limestone \\
ARS3 & 1.43 & 49.20 & 34.41 & 0.0291 & Magnesian Limestone \\
ARS4 & 1.60 & 48.67 & 30.42 & 0.0329 & Magnesian Limestone \\
ARS5 & 1.58 & 47.89 & 30.31 & 0.0330 & Magnesian Limestone \\
OKL6 & 1.39 & 52.31 & 37.63 & 0.0266 & Magnesian Limestone \\
OKL7 & 1.40 & 51.98 & 37.13 & 0.0269 & Magnesian Limestone \\
OKL8 & 1.40 & 50.06 & 35.76 & 0.0280 & Magnesian Limestone \\
OKL9 & 1.42 & 52.22 & 36.78 & 0.0272 & Magnesian Limestone \\
OKL10 & 1.40 & 52.04 & 37.17 & 0.0269 & Magnesian Limestone \\
MEAN & 1.52 & 50.06 & 33.31 & 0.0315 & \\
\hline
\end{tabular}

ARS: Arimogija Limestones, OKL: Okeluse Limestones

\subsection{Loss on Ignition (L.O.I)}

L.O.I reveals the content of volatiles present in the limestone deposit. The L.O.I value in the study area averages 40.4 .High L.O.I value is indicative of high volatile content and this suggests a high carbonate content since it is synonymous with the evolvement of carbon dioxide after heating at $1000{ }^{\circ} \mathrm{C}$ [24]. The fluctuation (increase or decrease) in $\mathrm{Fe}_{2} \mathrm{O}_{3}$ content may have a relationship with the terrigenous influx associated with high Iron bearing solutions. Higher amount of $\mathrm{Fe}_{2} \mathrm{O}_{3}$ in carbonate rocks reduces the absorption capacity which in turn lowers the rate of ignition of the samples

\subsection{Trace Element Geochemistry}

The trace elemental composition reported in ppm (Table 5) has the concentration of Sr ranging from $409-516 \mathrm{ppm}$ with an average of $460 \mathrm{ppm}$. $\mathrm{Zr}$ and Ba vary from 8-36 ppm and $10-25 \mathrm{ppm}$ with mean values of $22 \mathrm{ppm}$ and $18.3 \mathrm{ppm}$ respectively.

Trace elements analysis has been used in describing the conditions at deposition in specific depositional environment. It is a veritable tool used in the differentiation of shallow water and deep water limestones. Strontium and Manganese are markedly enriched in carbonate sediments. Hence, the enrichment of strontium in limestone is accounted for by the fact that $\mathrm{Sr}^{2+}$ substitutes readily for the very similar ion $\mathrm{Ca}^{2+}$. The smaller but appreciable concentration of manganese in carbonates is probably also attributable to similarity in ionic size.

\section{Strontium}

Flugel and Wedepohl, [25] reported relatively low Sr values (100-400 ppm) for shallow marine and relatively high Sr content (Oberalm limestone) for deeper water carbonates. Bausch [26, 27] also reported a high value of $\mathrm{Sr}$ (500-3000 ppm) which depicts a deep marine environment. Shallow water and deep water carbonates also have relatively low Sr (100-400 ppm) and high Sr values respectively [28]. The strontium ( $\mathrm{Sr}$ ) concentration in Arimogija-Okeluse Limestone indicates that the formation of the limestone under higher saline environmental conditions. 
Table 5: Trace Element Concentration (ppm) of Arimogija-Okeluse Limestone

\begin{tabular}{llll}
\hline SAMPLE ID & Ba & Sr & Zr \\
\hline ARS1 & 23 & 505 & 35 \\
ARS2 & 25 & 516 & 35 \\
ARS3 & 20 & 502 & 36 \\
ARS4 & 24 & 504 & 35 \\
ARS5 & 25 & 510 & 36 \\
OKL6 & 10 & 420 & 8 \\
OKL7 & 12 & 415 & 9 \\
OKL8 & 15 & 410 & 9 \\
OKL9 & 14 & 417 & 9 \\
OKL10 & 15 & 409 & 8 \\
MEAN & 18.3 & 460.8 & 22 \\
\hline
\end{tabular}

ARS: Arimogija Limestones, OKL: Okeluse Limestones

\section{Summary and Conclusion}

Limestone remains one of the industrial minerals with global use. Limestone is quarried for cement production in some part of Nigeria. However, the suitability of limestone production depends on its chemistry. This helps in the prediction of its purity.

The geochemical investigation of the Arimogija-Okeluse limestone was carried out to accomplish a chemical classification with respect to its chemical composition. It was revealed that $\mathrm{CaO}$ shows an inverse relationship with $\mathrm{SiO}_{2}$. The prevailing concentration of $\mathrm{CaO}$ with respect to $\mathrm{SiO}_{2}$ depicts its suitability for cement production.

The Todd chemical classification revealed that the Arimogija Okeluse limestone is the Magnesian type; with $\mathrm{Ca} / \mathrm{Mg}$ standard ratio range of 25.87-37.63 and a reciprocal ratio $\mathrm{Mg} / \mathrm{Ca}$ range of 0.030.04. The relationship between Alumina $\left(\mathrm{Al}_{2} \mathrm{O}_{3}\right)$ and $\mathrm{MgO}$ depicts a shallow marine environment for the Arimogija Okeluse limestone. The Trace element geochemistry also predicts the formation of limestone in shallow waters.

In general, the results obtained, however revealed that the Arimogija-Okeluse limestone is a Magnesian limestone type deposited in a shallow marine environment and suitable for cement production.

\section{References}

[1] S.A. Ola: Limestone deposits and small scale production of lime in Nigeria. Engineering Geology 11: (1977)127- 137

[2] M.A. Olade "Raw Materials for Cement Production after the Year 2000: Availabity, Suitability and Accessibility". National Workshop on Cement and Allied Products. Abeokuta, Nigeria. (1988).

[3] W. Gwosdz: Nigeria. In Bosse H. R, Gwosdz W, Lorenz W, Markwich, Rooth W and F Wolff 1996 (eds) Limestone and Dolomite resources of Africa. Geol. Jb., D, 102 (1996) 326-333

[4] A. Akinmosun, A.A. Odewande,, and A.I Akintola,.. Geochemical composition and Textural Features of some Carbonate Rocks in Parts of South Western Nigeria. Ife Journal of Science. 7(1): (2005) 101-111.

[5] O.A. Ehinola, A. Oluwajana, C.O. Nwabueze. Depositional Environment, Geophysical Mapping and Reserve Estimation of Limestone Deposit in Arimogija - Okeluse Area, SouthWestern Nigeria. Research Journal in Engineering and Applied Sciences 1(1) (2012) 7-11 
[6] A.T Bolarinwa ,S.O. Idakwo, T.S. Alege; Economic Aspects of Carbonates of the Albian Asu River Group in Tse-Kucha near Yandev, Middle Benue Trough, Nigeria. Journal of Geography and Geology; Vol. 5, No. 2; (2013) 85-98

[7] O.A Ola - Buraimo, O.A. Oluwajana., A. Olaniyan, A.O. Omoboriowo. Palynological Investigation of a Type Section of Early Maastrichtian Arimogija - Okeluse Shale Sequence, Dahomey (Benin) Embayment, Southwestern Nigeria. Int. J Sci. Emerging Tech Vol-3, (2012) Pp 37-45.

[8] R. C. C. Wilson and C. A. Williams 1979: Oceanic transform structures and the developments of Atlantic continental margin sedimentary basin a Review. In S. O. Olabode: Siliciclastic slope deposits from the Cretaceous Abeokuta Group, Dahomey (Benin) Basin, Southwestern Nigeria. Journal of African Earth Sciences, vol. 46, (2006) p. 187-200.

[9] S.J.L. Coker: Field Excursion Guide to Tar Sand Outcrops in Benin Basin. Nigerian Association of Petroleum Explorationists Mini- Conference, 2002 p. 32.

[10]H.G. Billman. Offshore stratigraphy and Paleontology of Dahomey (Benin) Embayment. NAPE Bulletin, 70 (02): (1992)121 -130.

[11]M.E. Omatsola, O.S. Adegoke. Tectonic Evolution and Cretaceous Stratigraphy of the Dahomey Basin. Nigeria. Journal of Mining and Geology 18 (01) (1981), 130-137.

[12]C.A. Kogbe. Paleogeographic history of Nigeria from Albian Times. In: C. A. Kogbe (ed) Geology of Nigeria. (1989) Pp. 257 - 275. Rock View International Tour Onyx Paris Cedix 13 France.

[13]J.D. Kantorowicz, I.D Bryant, and J.M Dawans: Controls on the Geometry and Distribution of Carbonate Cements in Jurassic Sandstones: Bridport sands, southern England and Viking Group, Troll field, Norway, in J. D. Marshall, ed., Diagenesis of sedimentary sequences: Geological Society (London) Special Publication 36, (1987) p. 103-118.

[14]M.A. Caja, R. Marfil, D. Garcia, E. Remacha, S. Morad, H. Mansurbeg, and A. Amorosi (2010): Provenance of Hybrid Turbiditic Arenites of the Eocene Hecho Group, The Spanish Pyrenees: Implications for Tectonic Evolution of a Foreland Basin: Basin Research, v. 22, p. $157-180$

[15] K.E. Chave. Aspects of the Biogeochemistry of Magnesium in Calcareous Marine Organisms. Jour. Geol. 62: (1954) 266-283.

[16] F.J Pettijohn, 1984. Sedimentary Rocks, 4th edition. Harper and Row: New York, New York, 1984.

[17] F.J Pettijohn. Sedimentary Rocks (3rd ed.). Harper and Row Pub. New York. 628p. 1975

[18]P.R. Ikhane, A.F. Folorunso, M.E. Nton, and J.A. Oluwalaanu. "Evaluations of Turonian Limestone Formation Exposed at NIGERCEM-Quarry, Nkalagu, Southeastern Nigeria: A Geochemical Approach”. Pacific Journal of Science and Technology. 10(2) (2009):763-771.

[19] A.A. Abdulraman and A.M. Ayuba. Anaysis of Limestone Samples Sourced from the Middle Belt Zone of Nigeria. Int. Jour. Pure and Applied Sci., 1(2), (2007) Pp. 1-8,

[20] D. Bejide. The Pore System Geometry and Diagenesis of the Albian Gboko limestone (Asu River Group) Middle Benue Trough, Nigeria. Unpublished M.Sc Research project. Unibadan. 2000

[21] S.S. Dada, J.L. Birck, J.R. Lancelot and M.A. Rahaman. International colloquium on African Geology, Mbabane, Swaziland, (1), (1993), 97-102.

[22] T.W. Todd: Petrographic classification of carbonate rocks. Journal of Sedimentary Petrology 36(2), (1966), 317-340 
[23] H. Marshner. Ca/Mg Distribution in Carbonates from the Lower Keuper in NW Germany (Development in Carbonate Sedimentology in Central Europe), Ed. (1968), pp. 127-135.

[24]J.A. Olatunji. Chemical characterization of Isale-osin marble, Kwara state. Geoscience Consultancy Report for Ministry of Commerce and Industry, Ilorin, Kwara state. (1989)

[25]H. W Flugel, and K.H Wedepohl, 1967: Die-vertielung des strontiums in oberjurassicchen karbonatgeserien Der Nordlichen Kalkalpen. Ein Bietrang Zur Dia geneses Von karbonate gesteinen contr Heidelberg. Mineral Petrology 14, 249-299.

[26] W.M. Bausch; Strontium gehalte in saddeutschen malmkalken.Geol Rdsch 55/1, (1965) 86-96. Stuttgart

[27] W.M. Bausch; Outlines of distribution of strontium in marine limestone. In:Muller, G. Friedman, G.M. (eds): Recent developments in carbonate sedimentology- Central Europe, (1968), 106-115. Berlin-Heidelberg. New York Springer.

[28] A.B. Ofulume: Using Geochemical Criterion to Check the Depositional Environment Derived From Fossil Content and Microfacies of the Shagamu, Mfamosing and Gboko Limestones, Nigeria; Journal of Applied Sciences Research, 8(1): 371-376, 2012 ISSN 1819-544X. 